\title{
Semiotic Analysis of a Poster about Violence against Women Violence
}

\section{Özgül Dağlı, Üsküdar University, İstanbul, Turkey \\ Elçin Hacıbektaşoğlu, İstanbul, Turkey}

\begin{abstract}
.
Semiology can be defined as the study of signs. As a method it can be applied to all sorts of human endeavours, such as cinema, theatre, dance, architecture, painting, politics, medicine, history, and religion. Saussure developed the principles of semiology as they applied to language; Barthes extended these ideas to messages (word-and-image relations) of all sorts. The mainstream semiology has offered a method for unravelling how the visuals and the texts of the posters work together to convey meaning, and how those meanings are connected to larger debates about modern life. As known, posters are quite complex systems in which different substances are engaged. But the semiologic analysis method can be applicable to every sort of human product. In this study researcher analysing a poster related to the violence against women. This poster is a special one, because it's rewarded by United Nations.
\end{abstract}

Keywords: Poster, semiology, semiologic analysis 


\section{Introduction}

Poster is a graphical expression of pictures and words or only words. Graphics and pictures in compositions visualize the text. However, the message of a text is conveyed to the target through letters and pictures together (Halldin, O. http://www.kb.se/docs/collections/historyposters.pdf). When poster is the subject, the first thing which people recall is cinema and theatre posters, the one used in political campaigns, the posters advertising concerts, exhibition new product or some other social activities. The visual regulations which are easy to comprehend and two dimensional as everybody knows have been a significant part of the society for many centuries. It has been used for various purposes such as to inform people, persuade them, change their thoughts, and mobilize them. Whereas its main purpose has changed by time, the area of its usage has kept growing. Thus, it may appear as a work of art used to increase people's awareness related to social problems nowadays. This study is about the analysis of such a poster.

Zeytinburnu municipality has had a poster prepared to attract notice to violence against women. This poster was found to be worth award by United Nations. In this study, the poster mentioned above was investigated with the use of semiology method. In this study, some knowledge will be given about posters, and then the poster subject to this study, will be introduced. After that, semiology model will be explained, and finally the award winning poster will be investigated with the use of semiology method.

\section{Poster}

Poster is a print material with some visuals which are posted in public places to make an announcement or advertise and to make propaganda (Büyük Larousse, Vol. 1: 124, 125). As pointed out in the definition above in the past "the places where public posters used to be posted were street walls. Nowadays, thanks to human intelligence and computer, sophisticated visual campaigns can be organized to mobilize people about taking measures for injustice, poverty and hunger. (Thompson, http://www.flickr.com/). Ertep explains the significance and function of poster as follows:

Poster is a means of communication which, from time to time, can tell new and different things to people, make them laugh, entertain them, warn and disturb as it is supposed to be, beyond being a means of enlightenment. It takes its main 
power as it fulfils its task sending sincere and effective messages enlightening, directing and persuading people (Ertep 2007: 80).

The advancements in the field of printing techniques, the emergence of coloured offset machines have made photographs subjects to poster printing in 1970s. Moreover, the novelties and convenience which were consequences of computer based graphical design have made posters more effective (Kaptan 1996). Posters are divided into different types with regards to the field which they serve in whereas their shared purpose is to achieve the goal flawlessly and influence receivers.

\section{Cultural Posters}

The posters in this field aim to attract people's attention to such organizations such as cinema, theatre, exhibition, seminar, concert, festival and sport by introducing these cultural activities to people.

\section{Social Posters}

Social posters which are used in the field of health, environment, traffic, policy, play significant roles in canalizing societies, spreading some knowledge, thought and disciplines. The posters making the harms of smoking and alcohol current issues, informing about the ways of staying away from illnesses and bringing forward some environmental problems, are good examples for such posters.

\section{Commercial posters}

The posters which are commonly used in the corporate advertising, industry, fashion, presspublishing and that aim to introduce a new product or service in the sector are all considered under the heading of this category. The most distinctive characteristic of this type is that it makes the target crowd consumers of a service or a product.

\section{Characteristics of a successful poster}

The poster which is the subject to this study is the one which was prepared to arouse social awareness for the violence against women. It is for sure that we cannot change the whole World with posters; however, we can influence the minds and thoughts of people. 
Social posters are works of art through which many problems that most people are aware but cannot visually express, are successfully depicted; just like a nice folk song. Poster is a work of art through which we can speak to everybody beyond the boundaries of language, culture and policy. A well prepared poster can have the potential to trigger discussions, thoughts and emotions (Lukova, http://www.posterposter.org/social-poster-design-advice/) Its mission is to mention about a good story to catch people's attention and send effective messages. Posters change people's ways of thinking and behaving. They can depict about injustice, disasters, gender apartheid and human rights and etc. (Loiri, http://www.posterposter.org/social-poster-design-advice/). In summary, posters are works of art which are used to arouse consciousness about some social problems.

\section{Semiology}

Semiology is a discipline studying both linguistic and non-linguistic systems (Gümüş and Şahin, http://dergi.mo.org.tr/dergiler/4/453/9359.pdf ) Semiology, with regards to the method it uses, attempts to explain everything (plays, gestures, facial expressions, religious rituals, literal works, audio tracks) through language; in other words, it tries to explain non-linguistic facts transforming them into language metaphor (Derviş Cemal, http://www.egeedebiyat.org/docs/493.pdf). Therefore, semiologic analysis is a kind of acquisition of reading skill and it aims to reveal the implicit meaning hidden behind the explicit meaning.

Ferdinan De Saussure is one of the most commonly known names, and he is also one of the founders of semiology. Saussure considers semiology as a discipline which investigates the structures of different semiologic types and the relationships among these types. Semiology, in his own words, is defined as "semiology teaches what signs are and what laws it is related to" (Saussure 1998: 46). According to him, as there are connections among the signs constituting the meaning, a sign has no meaning on its own.

\section{Sign, Signifier, Signified}

Saussure states that a sign consists of one signifier and one signified. The one signifier is a physical component of the signifier (voice, form and image), and the one signified is semantic component of the signifier. When you hear or see a signifier, its signified meaning comes into existence in our mind. What we mean to say is that there is not any natural relationship between the objects and any similarity relationships among the words which are equivalents 
of objects. For example, the relationship between the audial and written sign of the word "tree" and the concept of "tree" is totally arbitrary. We can know it because there is an associative connection between the sound of "tree" or its written form and the concept of "tree". The meaning is not hidden in that sound or writing, but in our mind. The combination of the sign in this example (the sound of tree or writing) and the concept of "tree" in our mind is called as signifier. The sound or writing of "tree" is the signifier and the concept of "tree" in our mind is the sign.

Therefore, signifier is "any type of object, creature or fact indicating something except itself" (Vardar, 1988:111). John Fiske de (1996: 63) defines signifier as something which refers to something except itself, which we can make sense with our sense. According to him, the existence of signifier is dependent on that users accept it as a signifier. Considering that, all words, gestures and mimics, fine arts and fashion products, the colours, figures and any architectural feature used on these fashion products in different languages are all signifiers, and they need to be investigated considering their relationships with the other signifiers in their environments (Rifat, 1992).

\section{Three Orders of Significations}

Three different levels of meaning or orders are used in the study of signs.

First level - when we start with the example of "tree" above, the systematic relationship between the signifier (tree sound or writing) and the signified (tree) is the first order of signification. Barthes called this stage; which Saussure has studied on, as denotative order of signification (Fiske 1996). The denotation in a message is perceived similarly by most of the people.

Second level: The meanings which cannot be or which are not inferred similarly by all receivers from the same message are named as the second order. The signifier and the signified are evaluated considering the meanings and values attributed by the society beyond the denotative meanings. This is the connotation of the signifier. For example, automobile itself in our society- or the sign of automobile- may refer to manhood or freedom. Connotation appears as reactions and associations resulted from interpersonal differences. (İmançer and Özer 1999). What makes the difference in giving the meaning to the signifier is the connotative meaning. Those indicating at the level of connotation refer values, emotions 
and attitudes. For example, the shooting angle in cinema, television and advertisements is used to connotate the connotative meanings in the music and illumination in the background.

Third level. The diversity in cultural differences appearing in the second level is evolved into the third interpretation level within the cultural interpretations. The automobile display above reminds us of an industrialized, materialist and rootless society at the third level.

\section{Semiologic Analysis.}

Barthes (1964) points out that semiologic analysis consists of two transactions. Dividing into pieces/analysing and combining. In the first transaction, when they come together (when they are related to one another) the pieces forming the meaning are investigated. Here, the person making the analysis focuses on the group elements which will form the meaning. The elements and the units which are related under some groups exhibit some series of characteristics. The two units of the same paradigm need to look similar to one another so that the differences between them are visible. For example, American cars look the same for foreigners; however, they are different in models and colours.

The second transaction, combining is related to the rules of bringing together. In brief, the person who makes the analysis takes the object, divides it into elements and then combines them again. In this stage, the person making the analysis makes visible the things which are not visible or not concrete (Seiler http://people.ucalgary.ca/ rseiler/semiolog.htm. Access date: 20.04.2015). Considering the study of Barthes (1977) "The Rhetoric of the Image" as the basis, the following transactions are suggested to be done in order.

1. Defining or summarizing the message conveyed to reader/viewer

2. Explain the key signifiers or signified elements.

3. Explain the paradigm exploited. Find out the signifiers forming the meaning.

4. Finally, determine the principle/core in the message or the text of the study.

\section{Linguistic Analysis of the Sample Poster}

The analysis of the sample poster was done based on the three stages of the interpretation. Seiler's stages given above were followed in this process.

The first stage. The woman whose photo was given place in the poster is at the age of between 35 and 40, with white complexion and blue eyes. Her hair is dark Brown and short. Shoulders are leftward in the picture looking across. 


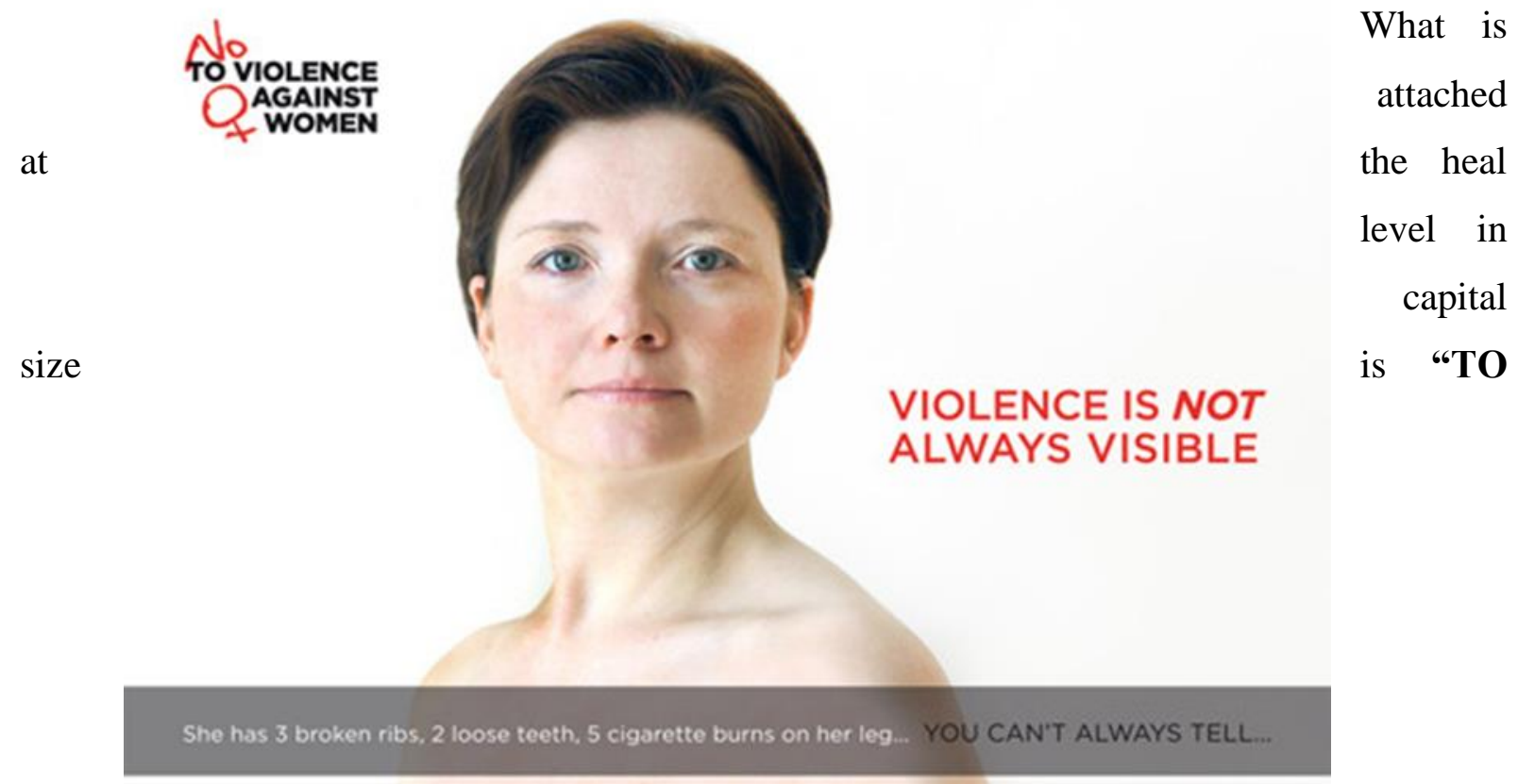

VIOLENCE AGAINST WOMEN". This writing is placed in the ad combining "no" with the symbol of femininity in red hand writing. On the right of the woman at the neck level "VIOLENCE IS NOT ALWAYS VISIBLE" is written in capital size and red color. The word "NOT" is written in italic form. The following statement "She has 3 broken ribs, 2loose teeth, 5cigarette burns on her leg... YOU CANT ALWAYS TELL...” is written on a black strip in white. 


\section{Second Stage}

The woman in the poster is extremely beautiful. She has almost no make-up, she looks quite modern, literate and healthy. Viewers catch the woman's eye at the first sight. The woman has a look of questioner, reproachful and she looks as if she wants to know what the audience thinks of. The word of "No" is handwritten adding to the writing "TO VIOLENCE AGAINST WOMEN" to clearify what the woman in the poster questions. The statement "VIOLENCE IS NOT ALWAYS VISIBLE" which is written in red on the right speaks out a significant dimension of violence againts women. The fact that the word "NOT" is written in italic and bold form in the statement pauses the audience, attracts their attention and encourages the audience to rethink of the meaning of the sentence. This is closely related to women's quizzical way of looking at events. It asks as follows "the real violence women are exposed in the society is not always visible, isn't it?" In the writing which was written small fonts which is hard to read; both the writing and the strip are associated with the rogatory looking of the woman and the woman herself in the poster. This is very clear. The strip is placed on the chest of the woman. This relationship can be seen more easily when the writing is read. The sadness which is sensed from the looking of the woman in the poster, the following extressions such as "three broken ribs, 2 broken teeth and 5 cigarette burns on the leg" are extremely though provoking. The statment placed at the end of the strip "YOU CANNOT ALWAYS TELL" makes a reference to desperation of women in the society. The upright standing of the woman in the poster expresses that when it is combined with her facial expression: maybe we put up with the unvisible, untold aspects of violence, which perhaps cannot be expressed for now, but we assure that our struglle will continue against it in the future.

\section{Third Stage}

The relationship built among different signifiers above points out two important dimensions of violence against women as a universal problem. The first is that all women are subject to violence. There is not relationship between being subject to violence and the following factors such as skin colour, physical appearance, modernity, level of education and etc. The second one is that, people are aware of some of the violence events against women. There are more violence events untold against women than what we hear and witness. Problem: it is a shared problem of all countries no matter a western or eastern country, rich or poor country. The violence against women results from the inequality in male-dominated societies, customs, 
traditions and Outlook of polytheistic religions to women, and its causes are very multidimensional. The endless and tireless understanding of agencies and institutes which also impoverish more and more people in the global World also need to be counted here.

\section{References}

Akerson, E. (2005). Göstergebilime Giriş. İstanbul: Multilingual Yayınları.

Barthes, R. (1996). Göstergebilim İlkeleri. Çev: Mehmet - Sema Rifat. İstanbul: Sözce Yayınları.

Kılıçoğlu S. ve Araz, N. (yayına hazırlayanlar). (1973). Büyük Larousse. Vol. 1: 124, 125

Ertep, H. (2007). Gündelik Yaşamımızın Ucundan Tutunan Bir Tasarım Nesnesi: Afiş. Grafik Tasarım Dergisi. October, Isue 13, p. 80-84

Fiske, John. 1996. İletisim Çalısmalarına Giriş. Çev.: Süleyman İrvan. Ankara: Ark Yayınları.

Greimas, A.J. (1995). Kusur Kousunda. Çev: Kıran, A. İstanbul: Yapı Kredi Yayınları.

Kaptan, A. Y. (1996). Afişte İllüstrasyonun Yeri ve Önemi. Yayımlanmammış Yüksek Lisans Tezi. Samsun: Ondokuz Mayıs Üniversitesi. 
Özer, Z. ve İmançer, D.(1999). Göstergebilimsel Çözümleme. SineMasal Dergisi. Bahar, p. 720

Parsa, A. F. (2008). Mutluluk Paradoksu Greimas'ın Eyleyensel Örnekçesiyle. İstanbul: Multilingual Yayınları.

Parsa, S. ve Parsa, A. F. (2004). Göstergebilim Çözümlemeleri. İzmir: Ege Üniversitesi Basımevi.

Rifat, M. (1996). Göstergebilimcinin Kitabı. İstanbul: Düzlem Yayınları.

Rifat, M. (1992). Göstergebilimin ABC'si. İstanbul: Simavi Yayınları.

Saussure, d. F. (1998). Genel Dilbilim Dersleri. Çev.: Berke Vardar. Multilingual.

Vardar, B. (1988). Açıklamalı Dilbilim Terimleri Sözlüğü, ABC Yay., İstanbul.

\section{Internet Resources}

Barthes, R. (1996). "The Rhetoric of the Image." In his book Image-Music-Text, trans. S. Heath. 1964; rpt. London: Wm. Collins Sons and Co., pp. 32-51. Inside Seiler, R.M. Semiology//Semiotics. http://people.ucalgary.ca/ rseiler/semiolog.htm. (access date: 01.03.2015).

Dervişcemal, B. Göstergebilim. http://www.ege-edebiyat.org/docs/493.pdf (access date: 01.03.2015).

Gümüş and Şahin. http://dergi.mo.org.tr/dergiler/4/453/9359.pdf (access date: 01.03.2015). Halldin, O. The History of Posters. http://www.kb.se/docs/collections/history-posters.pdf (access date: 01.15.2015).

Luba Lukova. http://www.posterposter.org/social-poster-design-advice/ (access date: 01.26.2015).

Michael Thompson. http://www.flickr.com/photos/freestylee (access date: 01.026.2015).

Pekka Loiri. http://www.posterposter.org/social-poster-design-advice/ (access date: 01.26.2015).

(http://sozce.nedir.com/) 